Author Details

\title{
Incorporating Global Components into Ethics Education
}

Dr George Wang

East Carolina University

Greenville, NC 27858

USA

Tel.: (252) 558-1704

Fax: (252) 328-1165

wangg@ecu.edu

Dr Russell G. Thompson

Senior Research Fellow

Institute of Transport Studies

Monash University

Clayton, Australia 3800

russell.thompson@monash.edu

+61399051850 (office)

+61 430972200 (mobile)

\section{Abstract}

Ethics is central to science and engineering. Young engineers need to be grounded in how corporate social responsibility principles can be applied to engineering organizations to better serve the broader community. This is crucial in times of climate change and ecological challenges where the vulnerable can be impacted by engineering activities. Taking a global perspective in ethics education will help ensure that scientists and engineers can make a more substantial contribution to development throughout the world. This paper presents the importance of incorporating the global and cross culture components in 
the ethic education. The authors bring up a question to educators on ethics education in science and engineering in the globalized world, and its importance, necessity, and impendency. The paper presents several methods for discussion that can be used to identify the differences in ethics standards and practices in different countries; enhance the student's knowledge of ethics in a global arena.

Key words: Ethics, global, construction, engineering

\section{Introduction}

Current science and engineering programs in higher education institutions provide students with sound technical knowledge. However, in the twenty-first century, science and engineering practices operate in many internationally different organizational and societal contexts. Science and engineering students need to be familiar with the differences in standards of ethics among different countries due to varied cultural, environmental, legal and political factors. These differences could affect scientists and engineers' judgment in design and various decisions, and could further influence every aspect in the global society including public welfare, the environment, sustainable economic development, and even moral values. Students, especially graduate students need to enhance their knowledge of ethics and responsible ethical practices so that they can work ethically and effectively in the global arena [1]. On the other hand, in the last several decades, the concept of ethics has been given broader connotations. For example, ethics is no longer limited to an individual's code of conduct; it involves the ethical practices of groups, for example, a company's corporate responsibilities [2-4].

Current ethics education curricula, either stand-alone ethics courses or ethics instruction through core courses, such as micro-insertion [5] do not usually provide both graduate and undergraduate students with training on international related ethical practices that reflect the changing world. To rectify this defect, globalization components need to be incorporated into ethics education. This includes content and teaching material enrichment, database establishment, pedagogy diversification, and curriculum development and reform.

\section{Background Information and the Necessity}

The necessity for research can be drawn from two aspects, (i) the inevitable trend of rapid globalization and (ii) the deficiencies of international related contents in the current ethics education.

2.1 Impact of the Globalization Trend - The world is becoming rapidly more globalized in various aspects. For example, engineers have more opportunities to work or pursue projects in international markets. Even in some traditionally domestic areas, scientists and engineers have to consider global factors, for example, when they deal with environmental and global warming issues they have to consider the effects from different countries and regions rather than 
individual countries. In the construction industry, foreign engineers, designers, and project managers may come to the United States to build the nation's infrastructure facilities; meanwhile, foreign investors are buying or forming joint ventures with domestic companies [6]. Scientists and Engineers now have to select materials or equipment manufactured by foreign countries for their designs or experiments. These decisions will affect every aspect of public welfare and safety. A high profile example is the drywall imported to the US from a foreign country that caused thousands of homeowners to be ill [7].

The second largest employer in the US, accounting for approximately $9 \%$ of this country's Gross Domestic Product (GDP), and incorporating professionals from various science and engineering fields is the civil and construction engineering sector. Ten to twenty years ago, international projects were conducted in developing countries by companies from developed countries [8]. However, in more recent years, there have been dramatic changes in the international construction market including construction companies, foreign engineers, and project managers from developing countries entering developed countries. For example, a Chinese construction company started the Alexander-Hamilton bridge renovation project, the largest single-phase project for the New York Department of Transportation in 2009 [9]. Construction companies from both developing and developed countries are forming joint ventures to conduct construction projects in developing and developed countries. The American/Nigerian joint venture which was awarded a gas-to-liquids plant construction contract [10] is an example of a joint construction venture. This implies that engineers and professionals in the US, even if they work in their own country, will need international knowledge, experience, or awareness of professional codes of conduct and ethics to work with their international partners.

On the other hand, the standards of ethics, which include individual codes of conduct and business ethics, have differences between countries, even though there are global efforts such as global compacts that uphold human rights between countries. In some countries, especially those countries having a unitary managerial system or economically underdeveloped countries there are practices that people in more economically developed countries would define as unethical that have become a way of life that people and government personnel have grown accustomed to. There are cultural differences also in what is perceived as ethical and what is etiquette. These ethical issues not only affect people and the economy, they affect all businesses in those countries including science and engineering sectors. As a result, science and engineering students are facing new challenges as they have more opportunities to be involved in international projects after joining the industry or starting their career. It is the educators' responsibility, challenge and opportunity to realize the challenges brought from globalization and the imperfection of ethical practices to (i) improve and strengthen ethics education, (ii) minimize the negative consequences and impacts, (iii) further enhance the individual's and organization's competitiveness from a humanistic, individual, and corporate perspective, through ethics education to improve society. 
For example, in China professional engineering associations are not independent of government agencies. Directors of professional associations are not elected by members of the association but are appointed and controlled by governments. Thus independent criteria, standards and professional ethical principles are not generally adhered to in China. Consequently, senior government officials and higher levels of government influence the culture and practice of the civil engineering profession with little attention given to technical specifications, quality assurance and project management.

In China, technical specifications for construction projects are developed by the government, not by independent technical committees. Thus infrastructure projects in China compared with the US often lack quality control and assurance systems due to poor levels of supervision. In China, the accountability of government officials is to higher levels of government and not to the people. This can lead to corruption. Lack of competition in tendering for large infrastructure projects often leads to a lack of innovation and efficiency in China compared with the US.

It is important for engineering students to understand how responsible behavior as professionals in foreign countries may be at a quite a higher level than is required by local laws. International standards and principles can be vastly different to local regulations or practices. Young engineers need to trained to apply world's best practices in quality management, environmental assessment and corporate social responsibility to ensure that local communities are not adversely affected by civil engineering works.

Civil Engineering students also need to be challenged in how to develop and apply procedures for ensuring that there are high levels of accountability and transparency in their financial transactions with local agencies and communities. This should include how to design appropriate stakeholder engagement mechanisms to ensure input from all concerned and interested parties. Student exercises in establishing discussion forums sensitive to local culture and customs can be incorporated into engineering ethics courses.

Young engineers also need to ensure that their activities do not contribute to climate change as the poor in developing countries are the most vulnerable to the effects of climate change and natural disasters. Students need to be trained in how to develop and implement appropriate and practical Occupational Health and Safety $(\mathrm{OH} \& S)$ procedures and employee wellbeing programs for local staff.

The need for incorporating an international context into ethics education is imperative. It has been observed that a notable number of graduate students expressed great interest in ethics issues. In a research paper assigned by the first author in a graduate course, 'Quality Management Systems', a student related product quality to ethics and corporate and government corruption. 
The student used an example from a third-world country, and pointed out that ethical issues could plague a country.

Several in-class surveys and interviews were conducted involving senior student groups over two consecutive academic years after international exchange activities, showed interesting changes in international perspectives. The data indicates that the number of students interested in international projects, joining a US international company, or pursuing professional career in overseas is increasing [1]. However, most students have little awareness of international market and projects, especially the differences including history, culture, political system among countries, and their derivatives including ethics. Students may think that project participants in an international project must adapt to all the conditions of a foreign country's ethical practices to maintain the control required for being successful, competitive, and profitable. It is crucial for educators to pass on fundamental and critical information regarding the differences in ethics to their students before they graduate, join an international company or work with international partners.

2.2 Introducing Global Related Components into Ethics Education - Limited information shows there is room for improvement in ethics education programs for engineers as well as other disciplines. The first step in improving ethics education is to conduct a thorough international comparative study. Little literature has reported this comparison, while some literature report individual (micro-ethics) ethics education practice from their countries [11-18]. The reform and improvement of ethics education can involve basic ethics teaching, methodology improvement, including the use of modern telecommunication technology, internet, hardware, and curriculum module development. The evaluation methods used will naturally be an important part of ethics education. Course material and content plays an important role for learning outcomes. Through effective ethics education, students should be able to solve dilemma issues in an international context, and differentiate between human errors and ethical issues. Case studies are an effective method to allow students to better understand global differences in ethics.

Much information developed in recent years that is relevant to individual or business ethics and codes of conduct can be reviewed and selected as global ethics topics. Some of the concepts may be popular in foreign countries, but not so common in the US. Comparative studies on ethics education and ethics practices will enlighten new concepts relating to global contexts and ethics. Leadership has been listed as one of the components in many universities' missions. Krishnasamy, who raised the issue of 'Better Humanity' [19, 20], listed ethics as the number one element of the four elements of 'leadership diamond' [21].

Since differences in values from different countries can be very wide, modules that provide standard values are important in international ethics courses. An example is the concept of Corporate Social Responsibility (CSR). CRS focuses on the accountability of organizations to a 
broad group of stakeholders including employees, customers, suppliers, community organizations, subsidiaries and affiliates, joint venture partners, investors and shareholders. CSR policies are based on social justice principles, human rights, and environmental standards. CSR can make our science and engineering students better understand that, 'we do not inherit the earth from our ancestors; we borrow it from our children' - a Native American quote. Fig. 1 presents components that relate to environment, social and economic issues which are the Triple Bottom Line. Balanced evaluations are necessary. It is important to let students understand non financial factors are crucial. Fig. 2 presents a CSR Spider Diagram which can be used for evaluating the performance of a corporation from an ethical perspective in (macro-ethics).

CSR is important to businesses as it enlightens self interest because corporations perceived as being socially responsible might gain from extra and more satisfied customers. Those perceived as irresponsible may face boycotts. High caliber personnel might be attracted to work for and be committed to more responsible firms. Voluntary commitment to social actions and programs might forestall legislation or other government action. Contributing to society is a long-term investment in a safer, better-educated, more equitable community. Hence firms can gain from a more stable business environment. A major principle of CSR is the chain of responsibility. Designers, engineers, and producers have a duty of care for the human rights and work practices of local communities to ensure the maximum benefits of sustainability, fewer impacts from climate change (including poverty alleviation and health), job security, and innovative staff.

Engineering ethics programs should also allow students to gain some experience in designing policies to ensure that the organisations they are employed by are operating consistent with current best practice in the area of corporate social responsibility. This not only relates to how employees, contractors and suppliers are engaged but identifying how the health and education facilities in local communities can be enhanced by civil engineering projects. The Millennium Development Goals produced by the United Nations provide a useful basis for developing corporate social responsibility policies and practices.

Comparing the Code of Ethics from different professional organizations and countries will provide a method to identify variations in ethical practices. Codes of professional conduct can help professionals make transparent what they are trying to achieve, and publicize the standards of personal behavior expected of such professionals. Such codes of conduct of professional associations help win public confidence and assist professions legitimize their control over the profession. Existence of such codes of conduct does not guarantee compliance by all members. Some companies also have formal codes of ethics, or sets of core values. Codes of ethics are the organization's general value system, moral principles that provide specific guidance to managers and employees regarding what is expected of them in terms of ethical behavior. Some organizations have ethics training programs which teach their employees how to predict and respond to ethical dilemmas that might arise in their jobs. 
A major aim of Engineers Australia's Code of Ethics [22] is, 'to respect the inherent dignity of the individual'. How to practice this in the engineering field is an important topic for students. Scientists and engineers selecting materials and equipment in their design introduces supply chain issues in a globalized economy. Current supply chains can cause desperation and death for many, especially in the Third World. How do supply chains benefit the poor and disadvantaged? Can we manage supply chains based on what our conscience demands? The Fairtrade concept that recently developed is becoming popular in countries such as Australia and the UK. Fairtrade Labeling Organizations (FLO) International is a non-profit, multi-stakeholder association (labeling initiatives and producer networks) that develops and reviews Fairtrade Standards and assists certified producers in gaining and maintaining Fairtrade Certification while capitalizing on market opportunities. Its strategic intent is to deliberately work with marginalized producers and workers in order to help them move from a position of vulnerability to security and economic self-sufficiency; to empower producers and workers as stakeholders in their own organizations; and to actively play a wider role in the global arena to achieve greater equity in international trade.

As future scientists and engineers, Savaidis stated that, 'we want a business that is financially sustainable but not to the extent of using workers that are exploited' [23]. The concept of Fairtrade will raise designs and productions and produce a range of sustainable and ethically manufactured products, which direct profits to every aspect of society.

The above basic concepts and many others will help students understand ethics and professionalism: 'an amateur practices until he/she can do something right; a professional practices until he/she cannot do it wrongly', and 'professional behavior is usually characterized by making decisions that are in the best interests of the client and not the practitioner' [24]. Professional services carry some moral responsibility and invoke some public interest or public good argument. But some professionals offer their services purely for pecuniary reasons [25]. Like in other subject areas, it is necessary to let students know that the process of life-long learning on ethics cannot be over-emphasized. Continued learning and education on ethics is important for society at large. Ethical problems do not have easily defined solutions but are usually surrounded by ambiguities, complexity and ill-defined boundaries. In a global situation, students should clearly understand that their project outcomes may have economic, legal and social costs as well as benefits. Table 1 summarizes the differences in business ethics between Europe, US and Asia.

\section{Possible Methodology}

Currently only 1 lecture hour per course is required to be devoted to ethics in both the Bachelor of Science in Construction as well as the Master of Construction at East Carolina University. The 
methods that could be employed to integrate global components into ethics education could be one or a combination of the two or more of the following: comparative study, lecture insertion, lecture exchange, research exchange, scholar exchange, students exchange or study abroad programs.

In a comparative study, a literature review is essential. It will be better to conduct national and international surveys. The literature review results and survey results can be used as lecture insertions for graduate students.

By means of telecommunication tools or distance education facilities, national or intentional lecture exchange can be performed. Lecture exchanges in ethics education have already been initiated.

Study abroad, or more commonly in the US, summer study abroad (SSA) programs are another method that can be used in an intensive education course on global ethics issues. Normally SSA programs are arranged for language students, very rarely from science and engineering fields. So far, no reports have been found of study abroad programs for ethics education. SSA will allow students to gain an understanding of the key issues of ethics in international contexts, such as cross cultural issues, overall managerial system, economic development level, social infrastructure, local technology.

In the summer of 2008, a three-week SSA program to China was organized by faculty members at ECU. Seventeen students participated in the study tour. In this summer study abroad trip, the team traveled to four major cities and provinces in China, and visited ongoing building and highway construction sites, attended panel discussions with construction professionals, students and faculty members from major academic construction and building science programs. Visiting various US companies in China gave students an active learning experience in culture and ethical issues when working in foreign countries. This short term study tour proved to be an effective and efficient way for students to learn international topics relating to many courses.

Other methods that can be used to strengthen ethics education in international contexts include research and scholar exchange as well as student exchange.

\section{Concluding Remarks}

In the rapidly globalized world with many unprecedented challenges, it is essential to realize the differences in standards of ethics among different countries and cultures that could affect scientists and engineers in their judgment, design and decision making and further influence public welfare, the environment, sustainable economic development, and even moral values. It is imperative that ethics educators provide students with basic training on international contexts in ethics. From a research viewpoint, it is necessary to conduct a thorough comparative study on ethics education and practices in different countries, identify the differences in ethics education and practices, and further to analyze the differences in ethics education and the differences in ethics practices. From an education viewpoint, through the research results ethics pedagogy can 
be improved; from the identified root causes and the cross impacts and consequences in an international environment (both positive and negative) to enrich ethics teaching contents. Furthermore, curricula and teaching materials can be developed. From these research and teaching activities students' ethics knowledge and the ability to differentiate professional and unethical conduct in an international environment will be enhanced. Principles can be developed that engineering projects and scientific experiments need to address including a range of local freedom, environmental, privacy, health and safety issues. Young engineers and scientists need to be sensitized to these areas and the potential impacts of their work and work practices, especially on health and education.

\section{References}

[1] Wang, G., Lu, H. and Ren, Z. (2010), Globalization in Construction Engineering and Management Education. Journal of Applied Research in Higher Education, 2(2), 51-62.

[2] Elder, K. E. (2004), Ethics Education in the Consulting Engineering Environment: Where Do We Start? Science and Engineering Ethics, (2004) 10, 325-336.

[3] Crane, A. and Matten, D. (2007), Business Ethics: Managing Corporate Citizenship and Sustainability in the Age of Globalization, $2^{\text {nd }}$ Ed. Oxford University Press, Oxford.

[4] Frederick, W. (1994), From CSR 1 to CSR2: The Maturing of Business-and-Society Thought. Business and Society, 33:150, 150-164.

[5] Davis, M. (2006), Integrating Ethics into Technical Courses: Micro-Insertion. Science and Engineering Ethics, (2006)12, 717-730.

[6] All Business (2005), Joint Venture Construction Contract Award for Planned Gas-To-Liquids Project. Available on line at: http://www.allbusiness.com/energy-utilities/oil-gas-industry-oilprocessing-products /797 13381.html.

[7] Sawyer, J. (2009), Drywall Imported from China Causing Construction Problems. Construction Litigation Law Blog on January 13, 2009. http://blog.njeifs.com/2009/01/drywall_imported_from_china_ca.html

[8] Raftery, J., Pasadilla, B., Chiang, Y., Hui, E. and Tang, B. (1998), Globalization and Construction Industry Development: Implications of Recent Developments in the Construction Sector in Asia. Construction Management \& Economics. 16:6, 729-737. 
[9] EU (2009), Chinese Construction Company Starts New York Alexander-Hamilton Bridge Renovation Projects. Government Updates, European Union Chamber of Commerce in China, 16 July 2009.

[10] All Business (2005), Joint Venture Construction Contract Award for Planned Gas-ToLiquids Project. Available on line at: http://www.allbusiness.com/energy-utilities/oil-gasindustry-oil-processing-products /797 13381.html.

[11] Maruyama, Y. and Ueno, T. (2007), Ethics Education for Professionals in Japan: A Critical Review. Philosophy of Education Society of Australasia, 2007 Conference Presentation, 8 pages.

[12] Christensen, S. H. and Kjolhede, E. E. (2008), Epistemology, Ontology and Ethics: 'Galaxies Away from the Engineering World'? European Journal of Engineering Education, Vol. $33: 5,561-571$.

[13] Song, S., Choi, K. and Rhee, H. (2010), Science and Engineering Major Students' Perception of Research Ethics and Education. KEDI Journal of Education Policy, (2010) 7, 175205.

[14] Boni, A. and Berjano, E. (2009), Ethical Learning in Higher Education: The Experience of the Technical University of Valencia. European Journal of Engineering Education, 34:2, 205213.

[15] Frey, W. J. and O'Neill-Carrillo, E. (2008), Engineering Ethics in Puerto Rico: Issues and Narratives. Science and Engineering Ethics, (2008) 14, 417-431.

[16] Børsen, T. (2008), Developing Ethics Competencies among Science Students at the University of Copenhagen. European Journal of Engineering Education, 33:2, 179-186.

[17] Fotheringham, H. (2008), Ethics Case Studies: Placing Ethical Practice in an Engineering Context. Innovation, Good Practice and Research in Engineering Education - The Higher Education Academy Engineering Subject Centre and the UK Centre for Materials Education EE2008, 1-3.

[18] McGregor, J. (2000), Practice-Focused Ethics in Australian Engineering Education. European Journal of Engineering Education, 25: 315-324.

[19] Krishnasamy, S. (2008), Comments on 'On 'Bettering Humanity' in Science and Engineering Education. Science and Engineering Ethics, (2008) 14, 291-293. 
[20] Stieb, J. A. (2007), On 'Bettering Humanity' in Science and Engineering Education, Science and Engineering Ethics, (2007) 13, 265-273.

[21] Koestenbaum, P. (2002), Leadership: The Inner Side of Greatness, A Philosophy for Leaders. John Wiley \& Sons.

[22] Engineers Australia, (2000), Code Ethics Engineers Australia.

[23] Savaidis, N. (2008), 'The Age’ April 18th, 2008, Melbourne, Australia.

[24] Kelly, J., Male, S. and Graham, D. (2004) Value Management of Construction Projects. Blackwell, Oxford. (p. 247).

[25] Low, L. (1996), Professionals at the Crossroads in Singapore. Times Academic Press, Singapore.

Table 1 - A Comparison of Different Business Ethical Behavior

\begin{tabular}{|c|c|c|c|}
\hline & Europe & US & Asia \\
\hline $\begin{array}{l}\text { Who is responsible for } \\
\text { ethical conduct in } \\
\text { business? }\end{array}$ & $\begin{array}{c}\text { Social control by the } \\
\text { collective }\end{array}$ & The individual & Top management \\
\hline $\begin{array}{c}\text { Who are the key actors in } \\
\text { business ethics? }\end{array}$ & $\begin{array}{l}\text { Government, trade } \\
\text { unions, corporate, } \\
\text { associations }\end{array}$ & The corporation & $\begin{array}{l}\text { Government, } \\
\text { corporations }\end{array}$ \\
\hline $\begin{array}{c}\text { What are the key } \\
\text { guidelines for ethical } \\
\text { behavior? }\end{array}$ & $\begin{array}{l}\text { Negotiated legal } \\
\text { framework of } \\
\text { business }\end{array}$ & $\begin{array}{c}\text { Corporate code of } \\
\text { ethics }\end{array}$ & Managerial discretion \\
\hline $\begin{array}{c}\text { What are the key issues } \\
\text { in business ethics? }\end{array}$ & $\begin{array}{l}\text { Social issues in } \\
\text { organizing the } \\
\text { framework of } \\
\text { business }\end{array}$ & $\begin{array}{l}\text { Misconduct and } \\
\text { immorality in single } \\
\text { decision situation }\end{array}$ & $\begin{array}{c}\text { Corporate governance } \\
\text { and accountability }\end{array}$ \\
\hline $\begin{array}{c}\text { What is the dominant } \\
\text { stakeholder management } \\
\text { approach? }\end{array}$ & $\begin{array}{c}\text { Formalized multiple } \\
\text { stakeholder } \\
\text { approach }\end{array}$ & $\begin{array}{c}\text { Focus on } \\
\text { shareholder value }\end{array}$ & $\begin{array}{c}\text { Implicit multiple } \\
\text { shareholder approach }\end{array}$ \\
\hline
\end{tabular}

Fig. 1 Components Relating to Economic, Social and Environment Issues

Fig. 2 (Right) CSR Spider Diagram - Enabling Organizations to Become Good Caretakers for Future Generations

Fig. 3 Fairtrade Label and Products 
Fig. 4 (Left) Dr. Russell Thompson from Monash University, Australia presenting a lecture to students at East Carolina University in North Carolina on Ethics and Corporate Social

Responsibility in January 2011

Fig. 5 (Right) Dr. George Ofori of National University of Singapore (NUS) presenting a lecture to Senior Undergraduate and Graduate Students on Ethics and Professionalism to Students at

East Carolina University in Fall 2009 through Online Distance Education System

Fig. 6 (Left) In the 2008 Summer Study Abroad to China Program, Students from ECU Visited American Companies in China. Students Receiving a Lecture on Business Ethics in China from the Fluor Corporation

Fig. 7 (Right) ECU Students interacting with Graduate Students of Tsinghua University, Civil Engineering and Building Science Departments in the Study Abroad Study Tour to China 
colour figure

Click here to download colour figure: Fig 1.doc

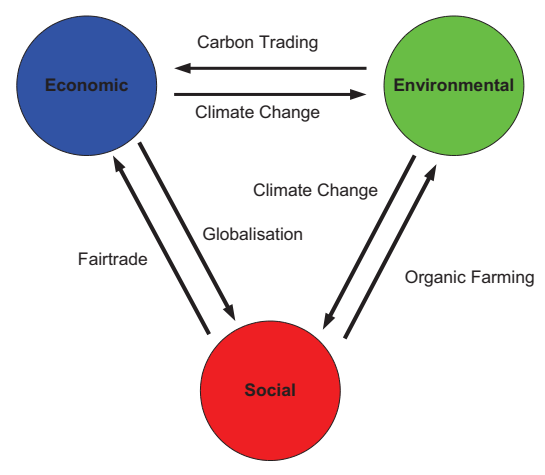


colour figure

Click here to download colour figure: Fig. 2.doc

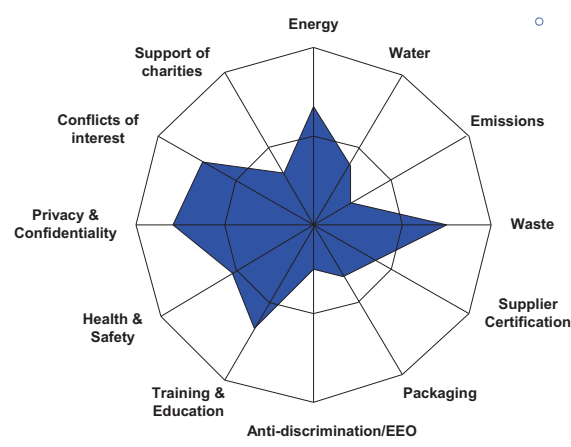


colour figure
Click here to download colour figure: Fig. 3.doc
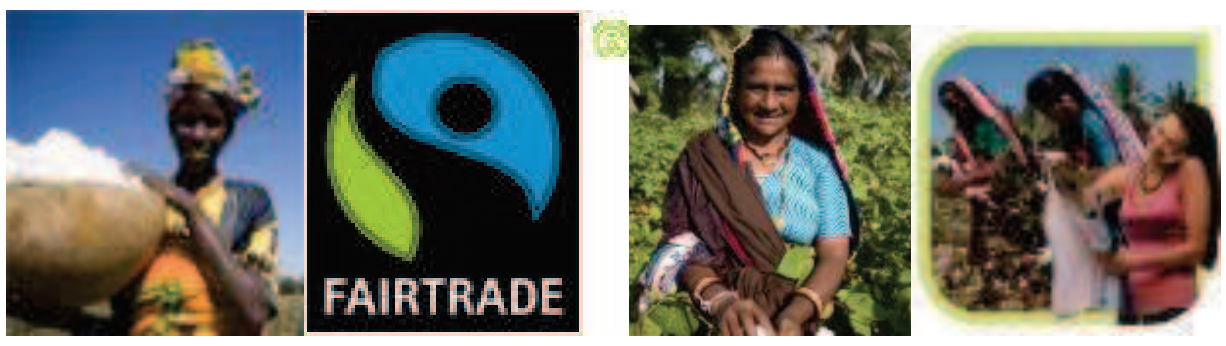
colour figure

Click here to download colour figure: Fig. 6.doc

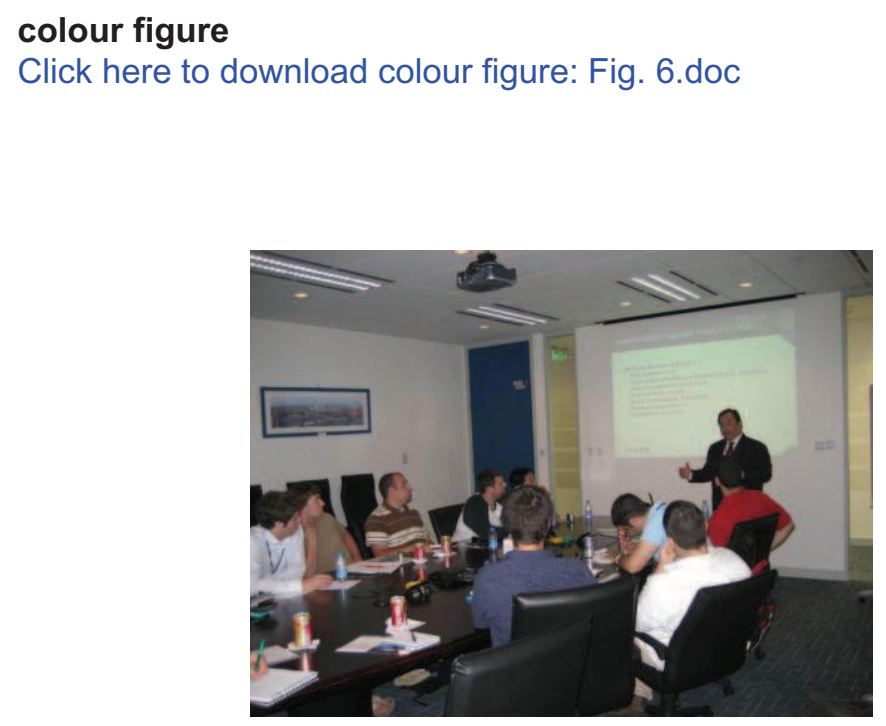


colour figure

Click here to download colour figure: Fig. 7.doc

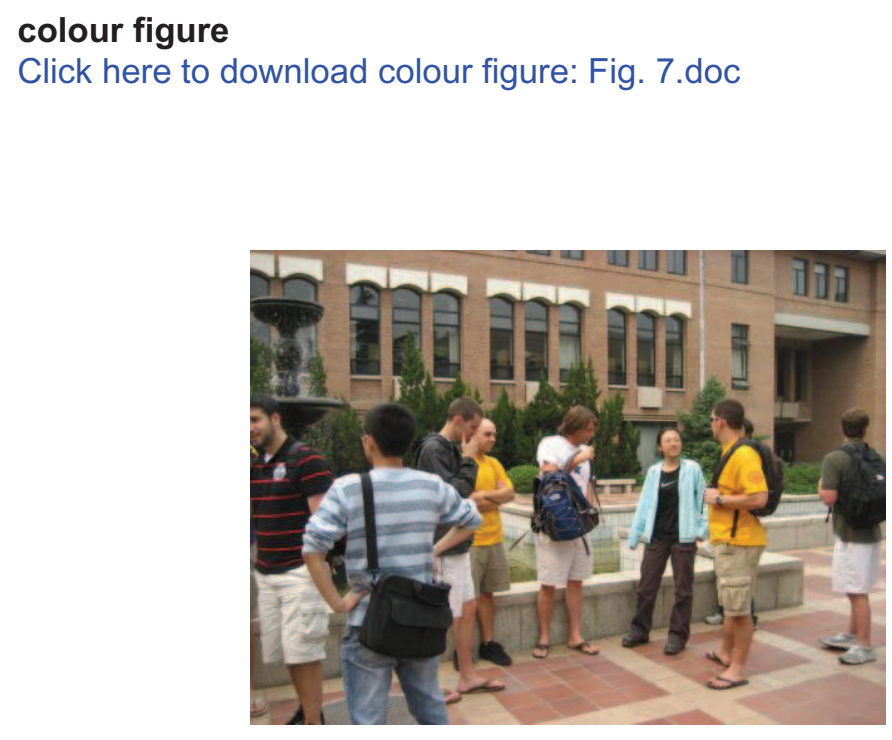




\section{University Library}

\section{- M M I E R R V A gateway to Melbourne's research publications}

Minerva Access is the Institutional Repository of The University of Melbourne

Author/s:

Wang, G;Thompson, RG

Title:

Incorporating Global Components into Ethics Education

Date:

2013-03-01

Citation:

Wang, G. \& Thompson, R. G. (2013). Incorporating Global Components into Ethics Education. SCIENCE AND ENGINEERING ETHICS, 19 (1), pp.287-298. https:// doi.org/10.1007/s11948-011-9295-X.

Persistent Link:

http://hdl.handle.net/11343/282971 